\title{
果 澍 園用除草 骫について
}

\section{果樹試験場興津支場 広 瀬 和 栄}

Kazuyoshi Hirose*: Herbicides for Weed Control in Fruit Tree Orchards

わが国の果樹園における除草剂の発達は近年めざまし $\langle 19,20,24,30,33,36)$, 落葉果樹, 常緑果樹を問わず年間 1 回 程度は使用されているものと考えられる。

現在の果樹園の成園, 未成園面積は第 1 表に示す通り で，カンキツ，リンゴ，カキ，ブドウによってその大部 分が占められている。当然のことながら未成園は草量が

第 1 表 果樹の栽培面積粠成（昭和 46 年度）

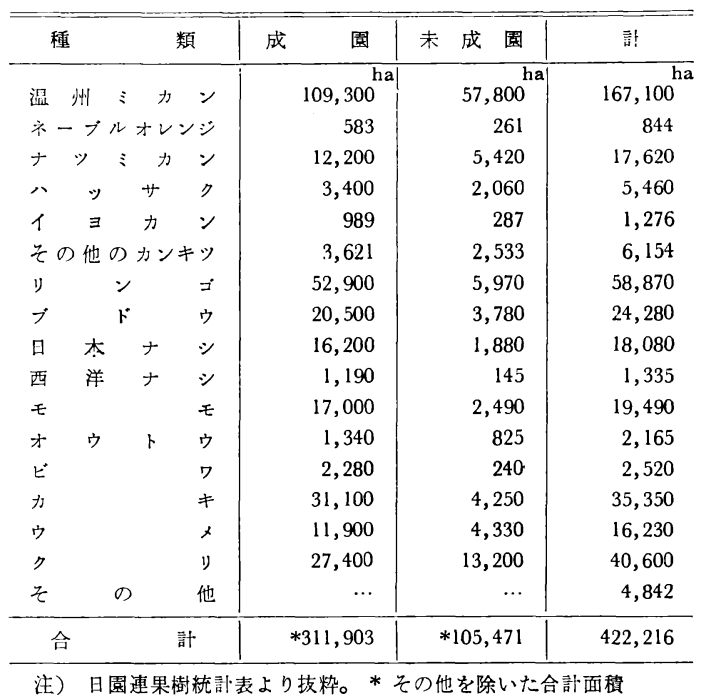

多いため除草剤の使用回数が多く, 成園では樹陰部が抑 草されるところから使用量は少ないものと考えられる。

果樹はその性質上，樹種・樹令などの果樹の条件と平 地・傾斜地のような立地条件によって土壤管理方法が 異なるため, 草の管理方法に差が生じ, 除草剤もその適 用が違ってきている。そのことをまとめて第 2 表に示 す。

この他に気象条件によって草管理に違いがあり，それ は草の生態の相違とともに, 土袞水分の競合, 肥料, 土 墒流亡などの影響を考慮する必要がある。例えば九州地 方では梅雨明け時期の集中豪雨, 瀬戸内地方では夏期の 乾燥, 東海地方では秋冷前線による雨, 関東地方では火 山灰地帯での肥料の競合, 東北地方では泠涼な気候によ る草生栽培との関係などがあって，問題を複雑にしてい
第 2 表 果樹の種類と草管理法（広瀬）

\begin{tabular}{|c|c|c|c|c|c|c|c|c|c|}
\hline & \multicolumn{2}{|c|}{ 若 } & 木 & \multicolumn{2}{|l|}{ 成 } & 木 & \multicolumn{2}{|c|}{ 除 草 } & 剤 \\
\hline & 清耕法 & \begin{tabular}{|c|} 
草 \\
株芯 \\
敷草 \\
\end{tabular} & $\begin{array}{c}\text { 生 } \\
\text { 株元 } \\
\text { 除草 }\end{array}$ & 清耕法 & 敷草 & 草生 & 理堙処 & 揬触哓 & 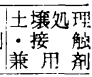 \\
\hline カンンキツ類 & 0 & (-) & 0 & 0 & 0 & () & 0 & 0 & () \\
\hline リ ข & & 0 & () & 0 & 0 & (2) & & () & 0 \\
\hline ブ ウ ウ & 0 & (2) & 0 & 0 & () & 0 & 0 & () & 0 \\
\hline 日本ナシ & 0 & 0 & (2) & 0 & () & 0 & & 0 & () \\
\hline 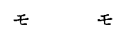 & 0 & () & 0 & () & 0 & 0 & 0 & () & 0 \\
\hline キ & 0 & 0 & ()) & 0 & 0 & () & & ()) & 0 \\
\hline$\eta$ & 0 & 0 & () & 0 & 0 & () & & 0 & \\
\hline
\end{tabular}

る。このことは, 瀬戸内地方で慣行化している清耕法を 九州地方で取り入れれば土壌流亡を助長するということ が起るので, 除草剂の適用も薬の種類, 濃度, 時期に違 いが出来てきて, 地域差が生じている。しかも草種や生 態型も, 九州から北海道まで一律に論ずることも出来な いこともあるので，ここでは一応カンキツ類を中心に考 えてゆきたい。

\section{1. 果樹園における雑草生龍}

果樹園における土壤管理方法は第 2 表に示した通り, 清耕法 (裸地栽培法), 敷草法 (被覆栽培法), 草生栽培 法, 草生敷草法（園内草生, 樹冠下敷草またはわら）が あり, 有機物の補給を考えて敷草または草生方法が一般 的であるが，近年敷草材料の不足から草生方法がとら れ，これの草管理に除草䨩が利用されてきているといえ よう。

果樹園に除草剂を利用する場合には，その雑草の生態 を知らなければならないし，除草凨によって生態型を一 部変えることが目的であると考えれば，そのことが重要 であることはいらまでもない。

果試興津支場 (静岡県清水市興津中町) ${ }^{13}$ ににおける雑 草の生態調査の一部を第 3 表に示す。この表で明らかな ごとく, 平地の果樹園では一般熟畑に近い草種が多く, 傾斜地ではそれに宿根草の侵入が認められる。また日陰 (樹冠下), 日なた（樹間）で草種が異なる。除草剤はこ の両方に有効でなければならない。他の栽培園との比較

* Fruit Tree Research Station, Okitsu, Shizuoka. 
第 3 表 日昭量の差と雑草群落の変化（7 月）(広瀬）

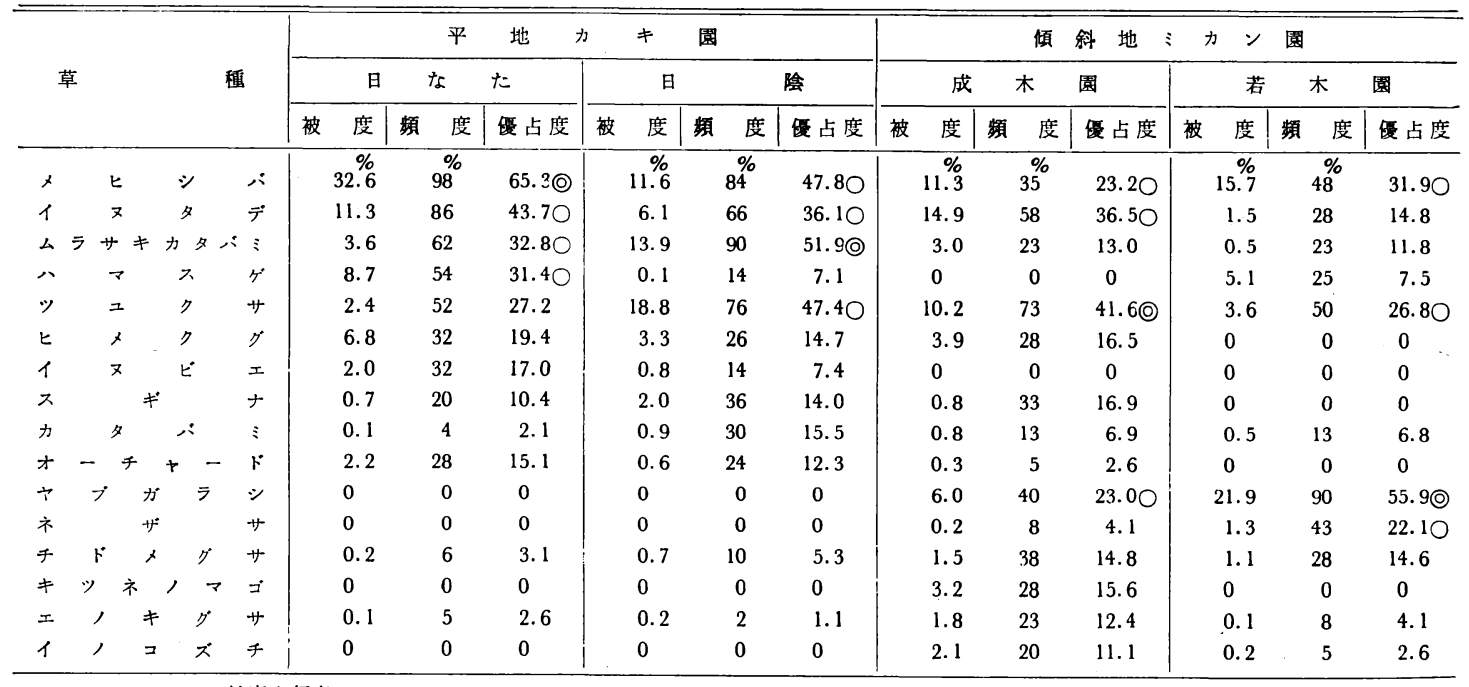

注）1）優占度 $=\frac{\text { 被度十頻度 }}{2} \%$, ○優占種，○次優占種

2）調查場所：静岡県清水市興津中町, 果試興津支場

では，果樹園において宿根草の侵入が目立つ。これは土 壌管理方法の違いとともに近年における機械化によって その伝播が助長されたことも考えられる。

果樹園における雑草生態の特徴をラウンケアの生活型 とあわせて沼田の分類 ${ }^{30)}$ によって示すと次のようにな る。

$$
\begin{aligned}
& \text { ミカン傾斜地テラス面は } \quad T h-\mathrm{D}_{4} \cdot \mathrm{D}_{1}-\mathrm{R}_{5} \text { 型 } \\
& \text { " のり面は } \mathrm{H} \cdot \mathrm{Th}-\mathrm{D}_{4} \cdot \mathrm{D}_{1}-\mathrm{R}_{5} \text { 型 } \\
& \text { " 開挀畑の面は } \mathrm{Th} \cdot \mathrm{H}-\mathrm{D}_{4} \cdot \mathrm{D}_{1}-\mathrm{R}_{5} \text { 型 }
\end{aligned}
$$

平地のカキ園における $\mathrm{Th}-\mathrm{D}_{4}-\mathrm{R}_{5}$ 型は $\mathrm{Th}$ (一年生植 物), $\mathrm{D}_{4}$ (散布型が重力のみ), $\mathrm{R}_{5}$ (根茎が単立茎であ る）といらことになり,一般の農耕地の特徴を示してい る。

ミカン傾斜地テラス面には $\mathrm{D}_{1}$ (風や水で伝播しやす いもの) が加わっているが，これはのり面から飛散しや すい種子形態をもつ植物の侵入があったためと考えられ る。同じくのり面には $\mathrm{H}$ (半地中植物) を意識的に増加 させたこともあってその量が多い。これは宿根草がのり 面の保全に重要であることを物語っている。これは原野 型である。

開墾畑はのり面によく似ている。これは前作物である マツ林の下草として住み分けていた植物が優占したと考 えられる。 $\mathrm{D}_{1}$ は飛散する植物の侵入がはじめに起るこ とを示しており，この場合はキク科のものが多かった。

このことからミカン園は, テラス面＝熟畑であり，の り面=原野であることが明らかである。熟畑はともする
と原野に引きもどされるため, 耕耘などにより熟畑への 進行および保持に努めてきたものと考えられる。これに 一般の除草剂を適用すればテラス面へ侵入した宿根草が 残り，優占して，テラス面を原野化することが考えられ る。

\section{2. 果樹園における益草と害草}

a ）害草 : ヤブガラシ，クズ, カラスウリ，ヒルガオ などのつる性草種は樹にからまり, 樹を覆う場合もあ る。そのような状態になると果樹に枯れ枝を生じさせた り，時として枯死させることもある。害草である。

b ）果樹園が利用している草：メヒシバ, ツユクサ, イヌタデ，八コベのような一年生草の多くは, 果樹との 間で土壌水分や肥料の吸収競合を生じない季節には草生 し, 競合する時期には除草するもので, 雑草草生の優占 種である。

c）利用はしているが，樹冠下に侵入してほしくない 草：原野型の土壤保全用に利用する場合には，ミカン園 では前述のよらにササ，チガヤ，ススキの類を，のり面 だけに住み分けさせておく必要があるが，それらが樹冠 下に侵入すると肥料などの点で競合が起るため, 侵入を 防止したい草種である。

d）害草でもなければ益草でもない草：暖地のムラサ キカタバミ，ハマスゲなどは，小型でもあり，大きな害 をすることもなく, 宿根草であるため完全防除は望めな いし，その必要もない。 


\section{3. ミカン園の草の消長と草管理}

ミカン園で利用する草を図に示すと第 1 図 ${ }^{13)}$ のとお りであり，秋生えの春草と春生えの夏草に分けることが できる。

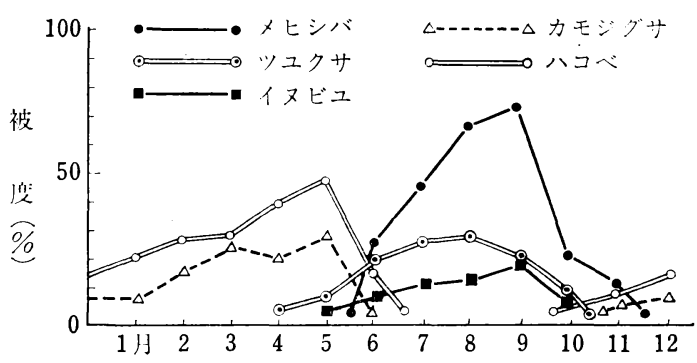

第 1 図 雑草の季節消長（静岡・興津）(広瀬）

注）調査場所 : 第 3 表汇同し

これらの草種の草管理（草刈りと除草剤使用）につい て示すと第 2 図拉よひ第 3 図のごとくで, その回数に差 がある。したがって草量に違いがあり，果樹園に供給さ
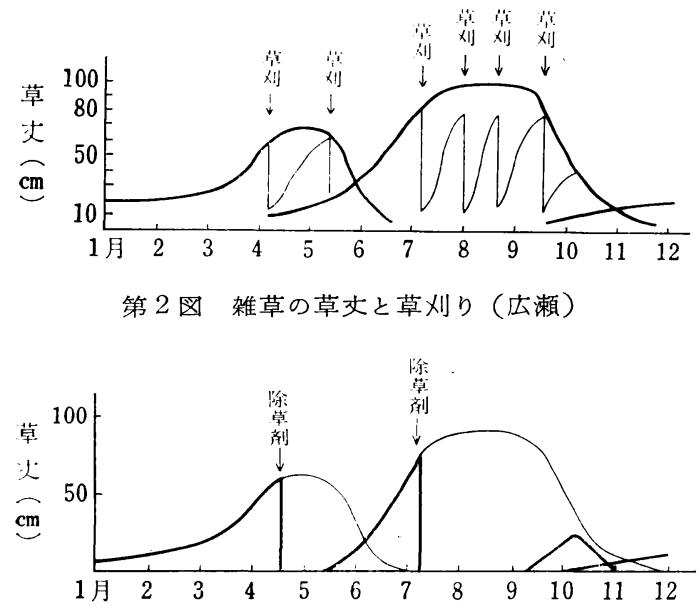

第 3 図除草剤を使った場合の草の生え方（広瀬）

注）除草剤を使用した場合の一年草の草の生兄方を模式的沉示し たものである。例えば，春草汇対する除草剤つメトリン，夏 草汇対してはブロマシルがこれ汇適合する。

れる有機物は除草剤を利用することにより減ずることと なる ${ }^{19,33)}$ 。このことは，省力効果だけに目を向けている ことの危険性を示唆しているとみてよい。しかし温州ミ カンの生育量は除草剤利用区において草刈区に比へ増加 が認められた。除草剤利用による省力効果は大きく，草 刈が鎌を用いて $10 \mathrm{a}$ 当たり 1 回に $5 \sim 8$ 時間を必要と し，年間 6 回刈取るとすれば総時間は 30〜48 時間とな るのに対し, 除草剤を使用すれば $10 \mathrm{a}$ 当たり動噴散布方
法で 1 回 $1 \sim 1.5$ 時間で足り, 年間 2 回の使用であるか ら $2 \sim 3$ 時間でよいこととなり, 顕著な省力効果 (1/10〜 1/24）がある。このことが除草剤の普及を促進した主な 要因であると考えられる。

\section{4. 果樹園用除草剤の使用時期}

果樹と草との間で競合するものは，一般作物で問題に なるような日照, 草いきれのような気象環境要素より も, 土壌環境要素すなわち土㙥水分, 肥料との競合が主 である。果樹との関係では $4,5,6$ 月が肥料の競合時期 であるが，草量から考えて 5 月の草が最も問題である。 また土壌水分との競合は 7,8 月である。このことから， 除草剂の使用を落葉果樹で 4,5 月, ミカン類で 5 月に 行なう。 6 月の梅雨期は土壌流亡が生じやすいので草生 栽培とし, 梅雨明けに除草剂を使用して, 梅雨中に生長 した大型 (30 70 cm 程度) の草を枯らし, それを 7,8 月に敷草にして土壤水分を保持するのが望ましい。秋生 えの草は翌春まで生育させてもよいが，ミカンでは秋期 に中耕して裸地状態にして土壤を乾燥させ，断根するこ とが果実の品質を向上させるため必要なので， 9, 10 月 は裸地にすることが望ましい。

\section{5. 果樹園用除草剤の条件}

a ）除草阂が土壌に浸透し，それが果樹の根から吸収 されて起る薬害 (土袞処理害) があってはならない。果 樹は永年生作物であることから，一度定植されると少な くとも 15 年以上，永いものは 60 年間もそこで生産を続 ける作物であるため, このような場合の土壌処理害は, たとえ処理した年だけの害が生じただけでもその後遺症 は数年間続くし，また土壌に蓄積して害を生じた場合に

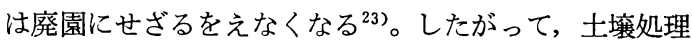
害の限界を実用濃度の 5 倍量として, この濃度で枯死に 近いような激しい薬害を生じないものを選抜する必要が ある。

b ）殺草効果が大型の草にまで認められること。前述 したとおり，梅雨明けに処理する場合には草は $30 \mathrm{~cm}$ 以 上に生育しており，九州地方では時として $1 \mathrm{~m}$ に達す ることもあるので, 発芽前処理剤 ${ }^{25)}$ では効果に問題が ある。それはわずかに若木の根圏, 苗木畑で使用される 程度である。

c ）抑草期間は肥料や水分との競合により影響され る。その必要期間は 4,5 月は 30 日程度， 7,8 月は 60 日程度が望ましいと考えられる。

d）果樹の茥葉に薬害のないことが望ましい。落葉果 樹でも茎葉害はなるへくないことが望ましく, 栽培方法 
によってそれを回避することができる。しかしミカン園 では枝が地面に近く，草と混在し，しかも段畑であるた めに茎葉に薬液が散布されやすいので, この条件はより 必要である。

e）防風林のような有用植物に害があってはならな い。

f ）果樹園は草種が多いので適用草種の幅が広いもの でなりればならない。

g ）果樹園内で住み分けている草種一一傾斜地のり面
のススキ, ネザサ, 草生栽培園のオーチャードグラスな ど—の生態型を大幅に変えないものであること。

h）人・畜・魚に無害でなければならない。

\section{6. 果樹園用除草剤の種類と特徵}

これまで果樹園用に供試した除草剤と実用性について 検討した結果は下記の通りである ${ }^{15,18,21,22,37,38,39) 。 ~}$

a ）実用性が認められ，実際に普及されている薬㶡の 特徴を第 4 表に示す。

第 4 表 現在実用化されている薬刘（広瀨）

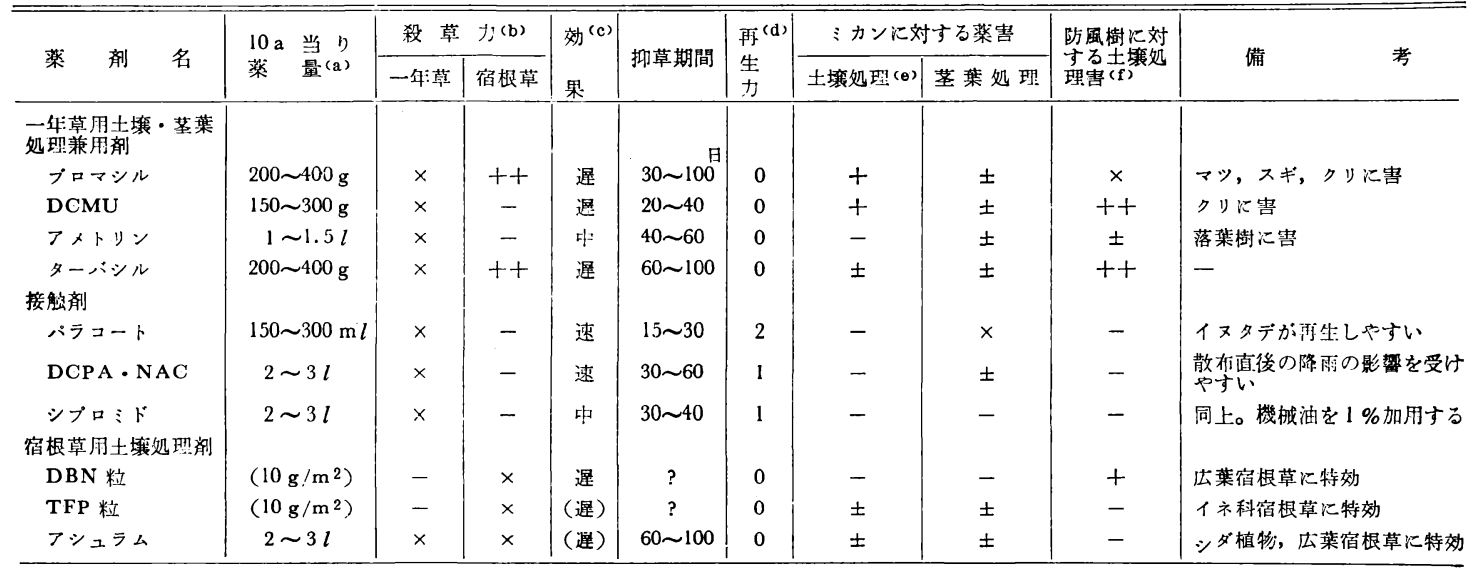

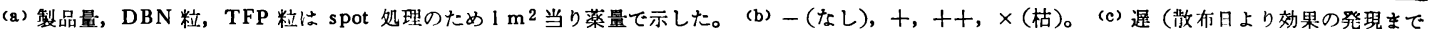

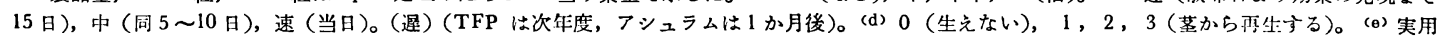

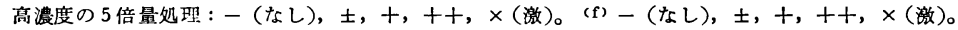

この表で明らかなよらに, 現在実用化されている薬剂 は接触剤系のものが多く, 土壤処理剤であっても展着剤 の加用によって接触効果をもたせており, 全くの土壌処 理剂として用いられているのではない。接触効果をもた ない土壌処理剤は, 苗木畑で使用されるか, パラコート のような純接触㶡に混用されているのが普通である。

そのほかに宿根草用の除草剂が使用されている。これ は原野 (のり面) からの宿根草の侵入があるためであ る。接触剤系の除草剤の使用が近年増加したため, 宿根 草の選択的増殖を助長したものと考えられる。

b ）実用性は認めたが，現在使用されていないか，使 用量の少ない薬剤とその理由をあげるとつぎのようであ る。

シアン酸ソーダ一一草の再生が早く, しかも再生後の 生育が旺盛なため，一時は使用されたが，後に開発され た薬剤に席を譲った。

エチルキサントゲンソーダ一一接触剤として有望であ ったが，覀臭が強く，実用にならなかった。

ATA—DCMU と混用で現在も使用されているが, 接触害が強いため, 使用量は減る傾向にある ${ }^{39,41)}$ 。
DPA一ーイネ科宿根草用に使用されているが, 効果の 点と砂壌土での薬害に問題があった。

アトラジン一ATA との混用で効果を認めたが，薬 害の点で実用にならなかった。

エンドタールー一接触剂として有効であったが，大型 の草種に効果が劣った。

ダイコート一一落葉果樹園では使用されているが, イ ネ科の雑草が多いためパラコートの使用が多い。

カコジル酸一一接触剤として実用性を認めたが，ひ素 の土裹残留が嫌われた。

$\mathrm{CAT}$ ・プロメトリン一一かり有望であったが, 特 徵にとぼしく，実用にならなかった。

リニュロン一一春草用として実用性を認めたが，夏草 には力不足で実用化しなかった。

シプロミッド—実用性は認められるが, 経済性の面 で実用化していない。

2,4-D——ヒルガオに使用されているが，ホルモン剤 であるため, 薬害の心配から多量には使用されていな い。

c）実用性を認めなかったもの。トリフルラリン， 
TIBA, TBA, PP-493, KH 171, To-11, UC 22463, モノリニュロン水和剤，グラスレスなどである。

d) 現在䳝験中の薬剤で有望なもの。MON-39, DC $\mathrm{PA}$ ・NAC 水和剤, アメトリン水和剂, DCPA 改良乳 剤, DCMU・ブロマシル， DCBN・ターバシルなどで ある。

\section{7. 除草剤の使用法について}

a ）展着剂の加用による土壌処理剤の接触効果の付 与：DCMU のような土壤処理剂に展着剂を加用するこ とによって接触効果が付与され $れ^{325,7,16,27,31,35)}$ ，またブ ロマシルやアメトリンについても展着剂（界面活性剂） の加用によって接触効果が付与され, 大型の雑草にも有

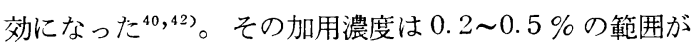
有効であることが明らかとなった。

b ）活性剤の加用による殺草初果の増加：DCPA に NAC を加用することにより， DCPA 単用よりも大型 雑草に効果があることが認められ，実用化された。これ は DCPA に有機燐剂やカーバメイト系殺虫剤が近接散 布された場合にイネに薬害を出したことから，DCPA の効果幅を広げることを目的として混䩹試験を行ない，

ミカンに対して薬害の少ない接触剤として実用化したも のである。現在は DCPAの乳化剤を改良して効果を高 めた薬剤の試験が行なわれている。

c）濃厚少量散布：パラコートのような接触剤は，ミ
カンの茥葉害は激しいが殺草効果の高いことから，使用 面積の広い薬殽の一つである。この薬剤について移行性 を試験し, 濃厚な薬液をメヒシバの葉身の中間に塗布し た場合，生長点に向って移行することを確認し，このこ とを利用して濃厚少量散布の試験を行なった（第 5 表）。

第 5 表 パラコートの濃厚少量散布の効果 $\left(1 \mathrm{~m}^{2}\right.$ の 生草量, 処理後 40 日目)（広瀬）

\begin{tabular}{|c|c|c|c|c|}
\hline \multirow{2}{*}{ 散 } & \multirow{2}{*}{ 布 } & \multirow{2}{*}{ 量 } & \multicolumn{2}{|c|}{ ハラコート濃度 } \\
\hline & & & $150 \mathrm{ml}$ & $300 \mathrm{ml}$ \\
\hline & $60 ?$ & & & $432 \mathrm{~g}$ \\
\hline & 30 & & & 441 \\
\hline & 200 & & 684 & 517 \\
\hline
\end{tabular}

その結果, このことは散布の省力化にもなり，また散布 水量が少ないため, 散布時の薬液飛散による薬害も少な くなるという利点が認められた。

d）宿根草に対する spot 散布 ${ }^{12,18)}$ : 宿根草は果樹園 全面に繁茂することは少なく，部分的に侵入してくるの が普通であるため， spot 処理を行ないらる薬剤を開発 し，粒状の DBN，TFP を実用化した。

e ）多目的自動散布用薬剤の開発：ミカン園ではスプ リンクラーを利用した自動散布装置が開発され, 病害虫 の薬剂防除が寒用化されつつあるため，これを利用して 散布できる除草凧の開発を行なって第 6 表の結果を得 た。まだ実用化には至らないが，これらの薬剤を基礎に して，近い将来に実用化のめどを立てたい。

第 6 表 自動散布装置による除草剤の散布試験（広瀬）

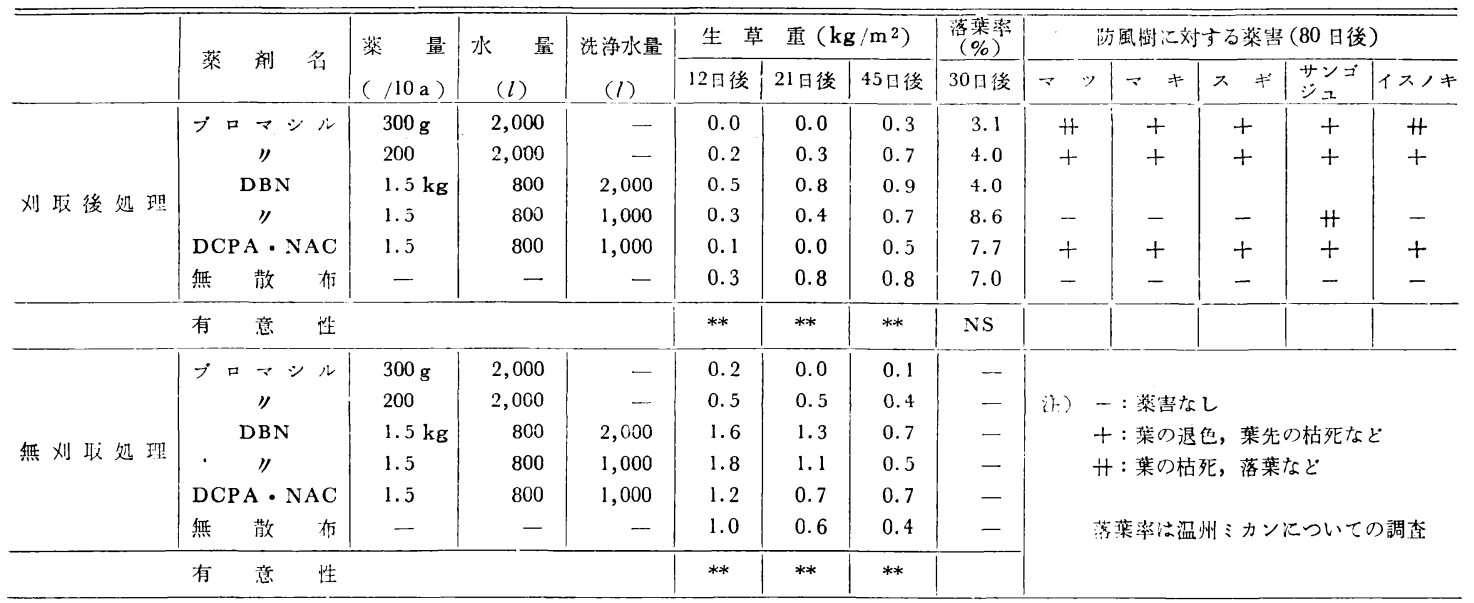

\section{8. 除草剤の選択性に関する研究}

$\mathrm{DCPA} \cdot \mathrm{NAC}$, シプロミド両薬剤のミカン葉中への 浸透について試験した結果，DCPA・NAC はDCA上
しては浸透を認めた。それでいて薬害が出にくいのは， 生理的に温州ミカンは影響を受けないためであろらと考 えた。一方, シプロミドは DCA の浸透量が温州ミカン で少なかった。この浸透量の差が選択性の違いであろう 


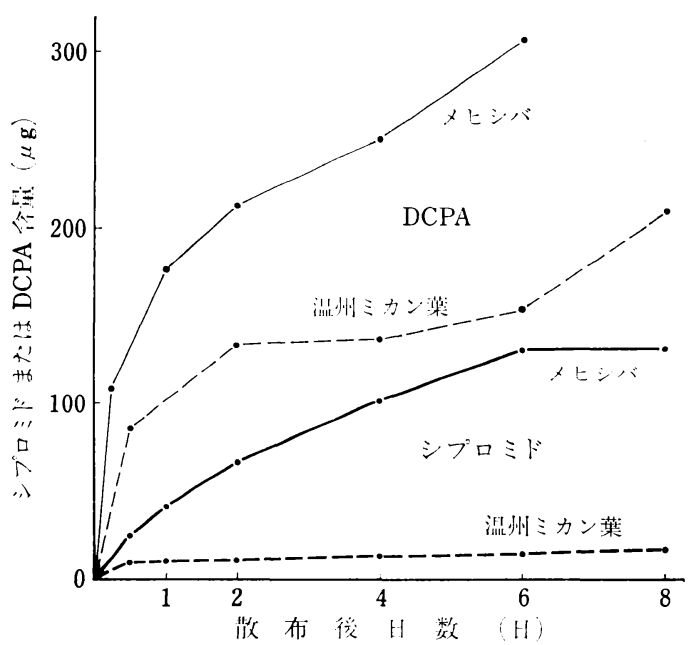

第 4 図 メヒシバとミカン葉への DCPA 並びにシ プロミドの侵入（広瀬）

と考えられた ${ }^{1,2,11,26,28) 。 ~}$

\section{9. 殺草効果と茎葉害との関係}

果樹に対して茎葉および土壤処理害がなく, 殺草効果 のある薬剤が望ましいことは言うまでもない。そのこと を充たすために, 接触凧のうちで茎葉処理害の少ない薬 剤を選抜することを目的として行なった試験結果を第 $\mathbf{5}$ 図に示す ${ }^{10)}$ 。この試験の範囲で殺草効果が高く, 落葉害

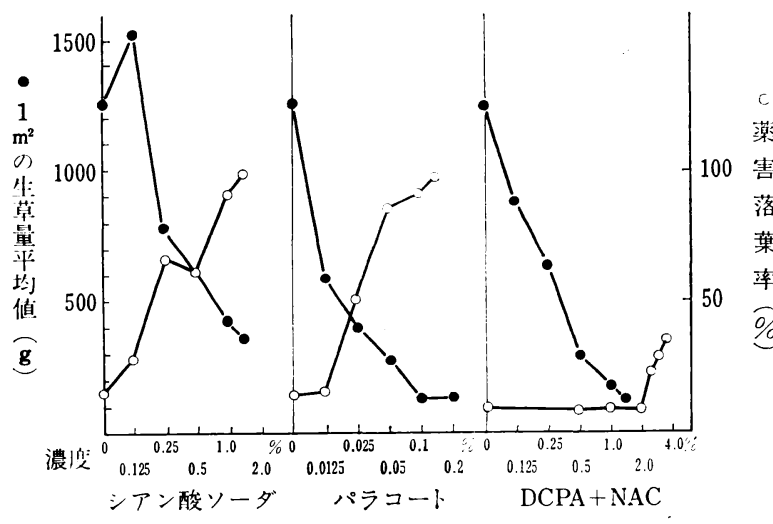

第 5 図接触剤のミカンに対する茎葉害と殺草 効果 (広瀬)

の少なかった薬剤は DCPA・NAC であった。このほ かアメトリン, シプロミド, DBN も同様の傾向であっ た。またブロマシル，DCMU，ターバシルは，接触隹 に比へて茎葉害が少なく, 散布しやすいが, 土壌処理害 および土壌残留についての危ぐがあった。

\section{0. 土壤処理と土壤残留に関する試験}

果樹は永年作物であるので，使用薬剤が土壌中に残留 して，薬害を起させるようでは廃園になるおそれがある ため, その点は他の作物に比べて厳重に注意する必要が ある ${ }^{29)}$ 。

現在ブロマシルについて, 経時的に, 土壌分析と生物 検定法によって ${ }^{32)}$ 生育阻害物質の残留について試験し ているが，その中間検討の結果で判断すると，土壤の質 によっても異なるが，処理されたブロマシルは約半年で 半量に減少し, 年 1 回の使用であれば問題のないことが 明確になった。また 12 年間にわたって年 2 回使用した 園 $^{13)}$ の温州ミカンに生育阻害が認められず，草の発芽 にも影響が少ないことが明らかとなった。

\section{1. 除草剤のローテーションについて}

単一の除草剤を連年使用すると草種の転換が起り, 選 択性のある草種が増殖することが認められ，その草種に も有効に働らかさせようとすると, 使用量を増加させる 必要があった。またパラコートのような茎葉処理害の激 しい薬剤を連年使用すると，果樹の下枝につく葉を枯死 落葉させ，生産性に影響するおそれがある。これらのこ と以外に, 土裹残留の点から考えても，一つの薬剤は数 年に一度の使用ならば問題なく, 環境保全から考えても 安全性の高い使用方法であると考えられる。しかし草生 栽培の草種転換を目的とした使用方法も考えられ，イネ 科草生からマメ科草生へ，またその逆にするといら利用 法ができれば，草と除草剤のより有効な利用法が確立で きるであろうと考えられる。

\section{2. 今後果樹園用除草剤に望むこと}

a ）土壌・茎葉処理により果樹に薬害の生じないもの

b ）草種の転換ができるだけ少ないもの

c ）宿根草にも有効なもの

d）土壤残留ができるだけ少ないもの

e ）防風樹にも薬害のないもの

f ）のり面および草生栽培園の草に対して雑草調節を 目的とした抑草効果のあるもの

g ）除草剂による方法でなく, 雑草生態を利用した雑 草調節法

\section{引用文 献}

1）足立明朗 - 利根川和江 ・ 上島俊治 : 農策生産技術 14，19 22 (1966).

2）足立明朗・利根川和江・上島俊治 : 農業生産技術 15, 11 14 (1966).

3) BAYER D.E. and H.R. Drever: Weeds 13 (3), 222 226 
(1965).

4) Bayer D.E., H.R. Drever and C. D. MCCarty: Calf. Citg. 41, 426,436, 438 (1956).

5) Bayer D.E., H.R. Drever and C.D. MCCarty: Calf. Citg. 49 (10), 371, 380, 382 (1964).

6) Day B.E., R. C. Russell and L.S. Jordan: Calf. Citg. 52 (7), 319, 333, 334, 336 (1967).

7) Hannon C. L.: Proc. Fla. St. Hort. Soc. 80, 59 63 (1967, 1968).

8）原田 豊・高原隆夫・坂本数夫：農及園 41 (9), 1373 1374 (1966).

9）広瀬和栄・原田 榓・六畑德輔: 園芸学会研究発表要旨, 昭 41 (春), 47〜 48 (1966).

10）広瀬和栄・吉田守・六畑德輔：園芸学会䂥究発表要旨, 昭 42 (春), $44 \sim 45$ (1967).

11）広瀬和栄・大炏德輔・餅田友紀子 - 小川安一：園芸学会仾究発表 要旨, 昭 43 (春), $28 \sim 29$ (1968).

12）広瀬和栄・富永信行・藤原 守: 園芸学会研究発表要旨, 昭 44 (秋), $30 \sim 31$ (1969).

13）広瀬和栄・八木正房：園試報 B 5, 165 182 (1966).

14）広瀬和栄：豊及園 43 (2), 359 363 (1968).

15）広瀬和栄：日本植調協報告, 昭 43, 44, 45, 46, 47 (1968 1972).

16) Hill G.D. JR., I. J. Belasco and H.L. Plogg: Weeds 13 (2), 103 106 (1965).

17）石田善一 - 渡部秀夫 ・渡部悦也 : 爱媛果試年報 5, 37 45 (1967).

18）石办邦作・真部辰夫：雑荸研究 16, 43 47 (1973).

19）岩川 孝: 農及園 48 (8), 1077〜1082 (1973).

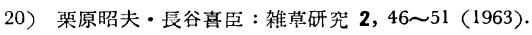

21）呇山隆明：農及園 45 (8)，1225～1229 (1970).

22）照上九三郎：農及園 41 (7), 1053 1057 (1966).
23) Lange A.H. and Crane J.C.: Proc. Amer. Soc. Hort. Sci. 90, 47 55 (1967).

24) Lange A.H., B. Fischer, D. Hamilton and H. AgayALIAN: Calf. Agr. 22 (10), 6 7 (1968).

25) Lange A.H., B. Fischer and G. Suthers: Calf. Agr. 23 (7), 7 8 (1969).

26) 松中昭一：雑草防除研究会第 8 回研究発表要旨, 26〜27 (1969).

27) MCWhorter C. G.: Weeds 11 (4), 265 269 (1963).

28）中村 拓・松中昭一: 雑草斫究 8, 33 38 (1969).

29）能勢和夫 : 杂隹草矿究 3，20 28 (1964).

30) 沼田 真: 植物生態学 I, 229 259 (1959).

31) 大畑德輔 : 杂隹草砄究 1, 47 49 (1962).

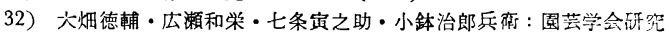
発表要旨, 昭 41 (春), 49〜50 (1966).

33）大畑德輔・広瀬和栄・山本弥然: 園芸学会研觉発表要旨, 顺 43 (春), $26 \sim 27$ (1968).

34）小野公二・神 昭二・菅野広義：農及園 $43(10), 1570 \sim 1572$ (1968).

35) Russell J.H.: Grower 66, 361 (1966).

36）七条寅之助・伊庭慶昭：農及園 39 (8), 123l 1235 (196t).

37) 田的 謙：農及園 41 (6), 907 911 (1966).

38）高木泉丑・新村逸郎・三田豊久: 静网析試資粘 89 (1965).

39) 博谷 勝・植木邦和: 杂隹草何究 3, 72 76 (1964).

40) 榑谷 勝・植木邦和: 杂草草研究 4, 86 89 (1965).

41) Temple R.E. and H.W. Hillton: Weeds 11 (4), 297 299 (1963).

42）植木邦和・傅谷 勝・真部 桂 : 雑草研究 2, 59 64 (1963).

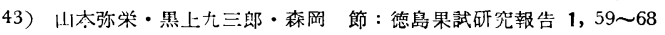
(1967). 